\title{
EVIDENTIARY PRIVILEGES IN THE FEDERAL COURTS
}

The status of state evidentiary privileges ${ }^{1}$ in federal courts is at best uncertain. In diversity litigation the interaction of Erie R.R. v. Tomp$k_{i n s}{ }^{2}$ and the Federal Rules of Civil Procedure has produced a variety of confusing rationales both for and against the application of state privilege law. In federal question hitigation the problem frequently has been overlooked or underemphasized. While most courts have assumed that state privilege law is irrelevant, ${ }^{3}$ the Ninth Circuit recently stated that even in federal question litigation federal courts are "required" to follow state privilege law. ${ }^{4}$ This Comment will explore the reasons for the present disagreement and discuss the considerations relevant to determining whether state law should control, with primary emphasis on what has been termed an "interest analysis" approach."

\section{A BRIEF HISTORY}

The history of state privileges in the federal courts prior to 1938 is relatively uncomplicated. ${ }^{6}$ Althougl there were decisions to the contrary, ${ }^{7}$

1 This Comment deals primarily with the attorney-client, accountant-client, and physician-patient privileges because they are the only privileges on which there is substantial federal case law. For a thorough discussion of the teclnical aspects of these privileges, see 8 WIGMORE, EvIDENCE §§ 2285-2396 (McNaughton rev. 1961).

2304 U.S. 64 (1938).

3 See, e.g., Colton v. United States, 306 F.2d 633 (2d Cir. 1962); In re Albert Lindley Lee Memorial Hosp., 209 F.2d 122 (2d Cir. 1953); Falsone v. United States, 205 F.2d 734 (5th Cir. 1953).

4 Baird v. Koerner, 279 F.2d 623 (9th Cir. 1960). Cf. United States v. Becton Dickenson Co., 212 F. Supp. 92 (D.N.J. 1962); Mariner v. Great Lakes Dredge \& Dock Co., 202 F. Supp. 430 (N.D. Ohio 1962) (also adopting state privileges as a rule of decision in a federal question case, but with rcasoning different fron Baird).

5 The concept of an interest analysis approach to source-of-law questions is not new in the federal systenl, although it has been used infrequently. Where it is used, as in cases dealing with the reach of federal power under the connnerce clause, e.g., Bibb v. Navajo Lines Inc., 359 U.S. 520 (1959); Southern Pac. Co. v. Arizona, 325 U.S. 761 (1945); South Carolina State Highway Dep't v. Barnwell Bros., 303 U.S. 177 (1938), and in the cases dealing with federal pre-emption, e.g., Huron Portland Cement Co. v. City of Detroit, 362 U.S. 440 (1960); California v. Zook, 336 U.S. 725 (1949), the basic issue to be decided seenus to be identical to that under discussion in this Conment: the accommodation of competing state and federal interests. Those cases therefore provide a proven methodology. Moreover, a recent "federal question" Suprenie Court case has specifically adopted an interest analysis approach. Kossick v. United Fruit Co., 365 U.S. 731 (1961). Cf. Stolz, Pleasutre Boating and Admiralty: Erie at Sea, 51 CaLre. L. Rev. 661, 701-05 (1963).

${ }^{6}$ See Callahan \& Ferguson, Evidence and the New Federal Rules of Civil Procedure, 45 YaLE L.J. 622, 632-34 (1936) ; Leach, State Law of Evidence in the Federal Courts, 43 HARv. L. REv. 554, 578-79 (1930).

7 In Connecticut Mut. Life Ins. Co. v. Schaefer, 94 U.S. 457 (1876), the Court Leld that 
it generally was assumed that privileges were governed by the Rules of Decision Act $^{8}$ which commanded conformity to state privilege law. ${ }^{9}$ As long as state privileges were statutory-which they were in every reported case-federal courts applied them whether sitting in law or equity..$^{10}$ Privileges became a problem only after Erie and the Federal Rules became law.

When Congress authorized the Supreme Court to promulgate uniform rules of procedure, ${ }^{11}$ the Court and Rules Advisory Committee immediately set to work to remedy the confusion which liad resulted from the federal system's conformity to "state rules of procedure. ${ }^{12}$ Unfortunately, even before the Rules became law the validity of some of them was placed in doubt by the decision in Erie R.R. v. Tompkins. Erie commanded, at least in diversity litigation, federal conformity to state rules of "substantive" law..$^{13}$ On the other hand, under the Rules Enabling Act $^{14}$ the Court's rule making power was limited to procedural matters. ${ }^{15}$ If "procedure" under the Federal Rules overlapped "substance" under Erie, a conflict existed. What the Rules called for in the name of uniformity, Erie would prohibit in the name of conformity.

This possibility of conflict became a reality when the Supreme Court held that federal courts in diversity cases are bound by any state law substantially affecting the outcome of litigation. ${ }^{16}$ Although the Court has generally avoided finding a direct conflict between the Rules

privileges were governed by the Competency of Witnesses Act, 34 Stat. 618 (1906), but failed to draw the technical distinction between competency and privileges. See Down v. Walls, 176 Fed. 657 (5th Cir. 1910).

8 See Connecticut Mut. Life Ins. Co. v. Union Trust Co., 112 U.S. 250 (1884); American Ry. Express Co. v. Rowe, 14 F.2d 269 (1st Cir. 1926).

828 U.S.C. $\$ 1652$ (1958): "The laws of the several states, except where the Constitution or treaties of the United States or Acts of Congress otherwise require or provide, shall be regarded as rules of decision in civil actions in the courts of the United States, in cases where they apply." Prior to 1948 "civil actions" read "trials at common law" thus ostensibly excluding cases in equity. See note 10 infra.

${ }^{10}$ Technically, before 1948 the Rules of Decision Act did not apply to actions in equity. There is authority, however, that the Act only codified what would have been the law anyway, and that it was therefore equally applicable in equity. See Bank of Hamilton v. Dudley's Lessee, 27 U.S. (2 Pet.) 492, 525 (1829). Apparently the problem of non-statutory state privileges never arose; but presumably under the rule of Swift v. Tyson, 41 U.S. (16 Pet.) 1 (1842), they would have been held inapplicable in federal courts.

11 Federal Rules Enabling Act, 28 U.S.C. $\$ 2072$ (1958).

12 The causes of this confusion and the ultimate result are set forth in detail in Callahan \& Ferguson, Evidence and the New Federal Rules of Civil Procedure, 45 YAIE L.J. 632 (1936).

13304 U.S. at $77-78$.

14 See note 11 supra.

15 "Such rules shall not abridge, enlarge or modify any substantive right. . . " 28 U.S.C $\S 2072$ (1958).

16 Guaranty Trust Co. v. York, 326 U.S. 99 (1945). 
and Erie, it has indirectly sapped the vitality of some of the Rules. ${ }^{17}$ This problem of conflict persistently plagues the lower federal courts, ${ }^{18}$ partially because of its inherent complexity and partially because of a judicial reluctance to accept a position requiring deference to state courts. $^{19}$

Generally speaking, where Congress has no power the federal courts have no power. ${ }^{20} \mathrm{It}$ is therefore necessary to assume for purposes of discussion that congressional power exists to legislate an across the board privilege rule for the federal courts. Given that assumption this brief history indicates that two imitial questions must be answered in considering the privilege source of law problem: (1) are privileges procedural under the Rules Enabling Act and thus within the Court's rule making power? (2) are privileges "substantive" under Erie? If both questions are answered in the affirmative the Federal Rules must yield. ${ }^{21}$ The principles underlying Erie seldom have been limited;22 on the contrary, the Supreme Court has consistently expanded their scope.

\section{II}

\section{Erie AND THE FEDERAL RULES}

The scope of the power conferred on the Supreme Court by the Rules Enabling Act is vague. The act provides that:

The Supreme Court shall have the power to prescribe, by general rules, the forms of process, writs, pleadings and motions, and the practice and procedure of the district courts ... in civil actions.

Such rules shall not abridge, enlarge or modify any substantive right . ...23

Surprisingly, neither the history of the act nor its subsequent construction by the Court or Rules Advisory Committee sheds any signif-

17 Ragan v. Merchants Transfer \& Warehouse Co., 337 U.S. 531 (1949), held that Rule 4(a) (action commenced by filing of complaint) does not toll a state statute of limitations. Cohen v. Beneficial Loan Corp., 337 U.S. 541 (1949), held Rule 23(a) provides only minimuin requirements for a shareholder elass action and that state law can impose greater requirements. Palmer v. Hofiman, 318 U.S. 109 (1943), held state law and not Rule 8(c) governs burden of proof as to contributory negligence.

18 E.g., Arrowsmith v. United Press Int'l, 320 F.2d 219 (2d Cir. 1963). But cf. National Equip. Rental, Ltd. v. Szukhent, 375 U.S. 311 (1964). Sec Note, 52 CaxzF. L. Rev. (August, 1964).

${ }^{19}$ See, e.g., State Law in the Federal Courts: The Brooding Omnipresence of Erie v. Tompkins, 55 YaIE L.J. 267 (1946).

20 See Degnan, The Law of Federal Evidence Reform, 76 HARv. L. Rev. 275, 288 (1962). An exception to this general rule may exist in admiralty. Sec Hill, The Erie Doctrine and the Constitution, 53 Nw. UL. REv, 427, 439-45 (1958).

21 See cases cited note 17 supra.

22 But see Byrd v. Blue Ridge Rural Elec. Co-op., Inc., 356 U.S. 525 (1958).

2328 U.S.C. $\$ 2072$ (1958). 
icant light on wliat Congress meant by "substantive." Because it initially doubted its power, ${ }^{24}$ the Advisory Committee dealt with evidence only hesitantly, primarily in a single, make-shift Rule-43(a) ${ }^{25}$ Rule 43(a)'s history within the Committee presents such a confused picture that it is difficult to say more than that the Committee had vague notions of some power to deal with some rules of evidence. ${ }^{26}$

In Sibbach v. Wilson \& $\mathrm{Co}^{2}{ }^{27}$ the Supreme Court made its only attempt at defining procedure under the Enabling Act. The result was not altogether satisfactory: "The test must be whether a rule really regulates procedure-the judicial process for enforcing rights and duties recognized by substantive law and for justly admimistering remedy and redress for disregard or infraction of them. ${ }^{\prime 28}$ If this is the test, privileges fall without it; to some extent at least privileges are in themselves rights. ${ }^{29}$ Rather than regulating the "judicial process" privileges cut across it by denying admissibility to evidence which may be both material and probative. Although Sibbach casts some doubts on the Court's power to promulgate rules affecting privileges, it is inconclusive. Consequently, the Rules themselves, and the construction placed on them by the judiciary, must be explored in some detail.

Two Rules, 26(b) and 43(a), have provided the background for

24 Premtamany Draft of the Rules of Civil Procedure for the District Courts xvii (1936). But see Proceedings of the Cleveland Institute on the Federal Rules 186 (1938).

25 See notes 34-41 infra and accompanying text.

26 The Committee initially told Congress that the Rules would affect no areas previously covered under the Rules of Decision Act, apparently equating the coverage of that Act with "substantive" under the Enabling Act. Hearings Before the House Committee on the Judiciary on the Rules of Civil Procedure for the District Courts, 75th Cong., 3d Sess. 141 (1938). In their final draft, however, the Committee admitted that the Rules did affect some matters of evidence previously covered by the Rules of Decision Act. FINAL DrafT OF THE Rutes of CIVIT Procedure for tHe District CoURTs of tHe UNTted States witH Notes To Rutes 90 (1938). Whether this included privileges is uncertain. The meaning the Congress gave these various statements is impossible to ascertain.

27312 U.S. 1 (1941).

28 Id. at 14.

29 Defining what is and is not a right presents considerable difficulty. Substantial authority exists to support the proposition that privileges are rights. Louisell, Confidentiality, Conformity and Confusion: Privileges in the Federal Courts, 31 ToL. L. Rev. 101 (1956); Weinstem, Recognition in the United States of the Privileges of Another Jurisdiction, 56 CoLun. L. REv. 535 (1956). But see Morgan, Rules of Evidence-Substantive or Procedural?, 10 VAND. L. REv. 467 (1957). The courts protect the privilege even after the active attorneyclient relation ceases, as where the client dies. 8 WigMore, EvDENCE \$§ 2323-27 (McNaughton rev. 1961). Further, the client is protected whether or not he is a party to the suit, 8 id. $\S 2321$, and he can enjoin the attorney from disclosing confidential communications without his consent. Meehan v. Hopps, 144 Cal. App. 2d 284, 301 P.2d 10 (1956). All of this indicates that the concept of privilege is closer to traditional notions of a right rather than a rule of procedure. 
most federal privilege litigation. Rule $26(\mathrm{~b})^{30}$ exempts privileged matters from discovery. Unfortunately, it fails to specify whether state or federal law determines what matters are privileged. One Supreme Court federal question case, United States $v$. Reynolds, ${ }^{31}$ involving a privilege of the federal government, held that Rule 26(b) refers to the "general law of evidence." Reynolds apparently lias been considered sui generis because subsequent cases are in hopeless conflict. ${ }^{32}$ In any event, because of the strong judicial belief in the efficacy of discovery-a belief greatly strengthened by the strictness with which privileges are construed in the federal courts-there is a tendency to resolve all doubts in favor of a procedural classification. ${ }^{23}$

Rule 43(a) deals more specifically with the source of evidence law in the federal system. It provides:

All evidence shall be admitted which is admissible under the statutes of the United States, or under the rules of evidence heretofore applied in the courts of the United States on the hearing of suits in equity, or under the rules of evidence applied in the courts of general jurisdiction of the state in which the United States court is held. In any case, the statute or rule which favors the reception of evidence governs ....

In retrospect it is difficult to imagine a more poorly phrased Rule. Because it is written in terms of admissibility Rule 43(a) apparently fails to cover rules of exclusion such as privileges. ${ }^{34}$ When evidence is privileged under state law, Rule 43(a) provides only two sources for admission, federal statutes and prior federal equity practice. Federal statutes are of little assistance in the privilege area because they are practically non-existent. This leaves only prior federal equity practice as a source. Because of the nature of equity proceedings, however, specific

30 "[T]he deponent may be examined regarding any matter, not privileged, which is relevant to the subject matter involved in the pending action ...."

31345 U.S. 1 (1952).

32 See notes 44-49 infra and accompanying text.

33 Hickman v. Taylor, 329 U.S. 495 (1947), which sets forth the concept of "work product," has been a primary stumbling block to a substantive classification of privileges. What Hickman classified as "work product" has been classified by some states as a matter of privilege. Federal courts sitting in such states have therefore assumed that Hickman stands for the proposition that privileges are procedural under Erie. See Brookshire v. Pennsylvania R.R., 14 F.R.D. 154 (N.D. Ohio 1953); Holbert v. Chase, 12 F.R.D. 171 (E.D.S.C. 1952). Hickman, however, is weak authority for that proposition. It was a federal question case arising under an admiralty statute and therefore involving a federally created right. The Court did not discuss Erie or state law and probably did not consider the potential effect of Hickman on diversity litigation. Moreover, Hickman specifically stated it was not dealing with privileges. 329 U.S. at 508. Nevertheless, Hickman, and the privilege diversity cases citing it, indicate the strong feeling the federal judiciary las for discovery.

34 Rule 43(a) and its problems are well analyzed in Green, The Admissibility of Evidence Under the Federal Rules, 55 HARv. L. Rev. 177 (1941); Comment, 48 VA. L. REv. 939 (1962); Note, 46 Colum. L. Rev. 267 (1946). 
federal equity precedent for most rules of evidence, including privileges, also is virtually non-existent. ${ }^{35}$ In Monarch Insurance Co. v. Spach, ${ }^{36}$ the court resolved this problem by adopting what should become the definitive construction of Rule 43(a). It reasoned that prior federal equity practice must be more than a reference to specific precedent; rather, it must refer to the technique an equity court would have used in determining admissibility. ${ }^{37}$ Since that technique involved a broad search for the evidentiary rule which best suited the case at hand, whether of admission or exclusion, the loolding in Monarch should lead to a new approach in the federal courts' handling of exclusionary rules. ${ }^{38}$

Assuming, under this broad interpretation of Rule 43(a), that federal courts are free to search for the most preferable rules of privilege, the freedom is restrained by Erie R.R. v. Tompkins. To date the primary thrust of Erie has been the well-known "outcome determination" test. That test seems to represent primarily a judicial dislike of "forum shopping." ${ }^{339}$ It is submitted that outcome determination is but one level of Erie: the case reflects fundamental notions of our federal system which are not exhausted by the outcome test.

Erie recognizes that federal judicial power is not necessarily coextensive with federal legislative power..$^{40}$ Thus, there are many areas where congressional power is clear, but where, in the absence of an exercise of that power, the court's lawmaking function is curtailed. Two reasons have been advanced for this curtailment. First, in areas where the courts lack competence, imitial policy decisions are best made through the legislative process. For example, the judicial process is not suited to determining tax consequences when a state levies a tax that indirectly imposes an "economic burden" on the federal government..1 Consequently, in the absence of congressional action federal courts have generally respected state legislative decisions dealing with imter-governmental taxation. Second, the function of the adjudicatory process is to decide narrow issues on specific facts rather than to enunciate sweeping rules of conduct. ${ }^{42}$ Thus, even where judicial competence exists a federal court may hesitate to act in advance of Congress.

\footnotetext{
35 Comment, 48 VA. L. Rev. 939, 944 (1962).

36281 F.2d 401 (5th Cir. 1960).

37 Id. at $409-11$.

38 Subsequent cases are adopting the Monarch approach. See, e.g., Hope v. Hearst Consol. Publications, Inc., 294 F.2d 681 (2d Cir. 1961), cert. denied, 368 U.S. 956 (1962) ; Hambrice v. F. W. Woolworth Co., 290 F.2d 557 (5th Cir. 1961); Dallas County v. Commercial Union Assur. Corp., 286 F.2d 388 (5th Cir. 1961).

30 Degnan, The Law of Federal Evidence Reform, 76 HARv. L. REv. 275, 288 (1962).

40 Hart, The Relations Between State and Federal Law, 54 Coros. L. Rev. 489, 495-99 (1954).

41 United States v. City of Detroit, 355 U.S. 466, 474 (1958).

42 Hart, supra note 40 , at 496 .
} 
Finally, at what seems to be its highest level, Erie recognizes that in a system of dual sovereignty the system's balance is upset when the officials of one sovereign interfere with the interests of the other. ${ }^{43}$ Initially, of course, the federal government's interests are limited to the powers enumerated in the Constitution. Generally, however, some constitutional power is present, the question being its extent. It is in determiming this extent that the interest analysis approach is useful. The interest analysis approach is simply a recognition that in a federal system relative interests must be weighed in determining applicable law. It has been widely adopted in other source of law areas ${ }^{44}$ and, it is submitted, it should be adopted in analyzing what are commonly called "Erie problems."

\section{III}

\section{AN INTEREST ANALYSIS APPROACH TO PRIVILEGES}

\section{A. Diversity Litigation}

The diversity privilege cases are generally so confused that they provide hittle guidance. Some are completely useless because they apparently fail to see that there is a problem..$^{5}$ The majority of the cases does recognize that privileges present a conflict between Erie and the Rules, but radically different results are reached. One line of cases adopts the view that a statutorily created state privilege controls even though more restrictive than federal precedent, but that federal law controls in the absence of a statute. ${ }^{46}$ Unfortunately, it is not clear whether this result is reached under Erie or the Federal.Rules. If the former, it is the very interpretation of "laws" struck down by Erie, and consequently an unacceptable basis for decision. If the latter, its basis in the Rules is unclear. A more reasonable bine of cases relies on Professor Moore's analysis. Moore reasons that the Federal Rules rather than Erie control privileges because under the outcome determination test privileges are procedural. ${ }^{47}$

\footnotetext{
43 For discussion of this concept, see Degnan, supra note 39, at 288; Hill, The Erie Doctrine and the Constitution, 53 Nw. U.I. Rev. 427, 451 (1958); Mishkin, The Variousness of "Federal Law": Competence and Discretion in the Choice of National and State Rule for Decision, 105 U. PA. L. REv. 797, 798-801 (1957).

44 See, e.g., Kossick v. United Fruit Co., 365 U.S. 731, 738-41 (1961).

45 Engl v. Aetna Life Ins. Co., 139 F.2d 469 (2d Cir. 1943); Car \& Gen. Ins. Co. v. Goldstein, 179 F. Supp. 888 (S.D.N.Y. 1959); Stiles v. Clifton Springs Sanitarium Co., 74 F. Supp. 907 (W.D.N.Y. 1947) ; Munzer v. Swedish An. Lines, 35 F. Supp. 493 (S.D.N.Y. 1940); Lewis v. United Airlines Transp. Corp., 32 F. Supp. 21 (W.D. Pa. 1940).

46 Palmer v. Fisher, 228 F.2d 603 (7th Cir. 1955), cert. denied sub nom. Fisher v. Pierce, 351 U.S. 965 (1956); Anderson v. Benson, 117 F. Supp. 765 (D. Neb. 1953); see Note, 44 CaLIF. L. Rev. 949 (1956).

475 Moore, Federal Practice § 43.07 (2d ed. 1961). Cf. 2B Barron \& Holtzoff, Fed-。 erai Practice \& Procedure § 967 (Wright rev. 1961).
} 
Within this line of cases there is a split of authority as to whether Rule 43 (a) requires adherence to state law ${ }^{48}$ or whether the court is free to make its own law. ${ }^{49}$ The discovery cases in this he hold that state privilege law is entitled to respect but is not controlling. ${ }^{50}$ A final group of cases recognizing the interaction of Erie and the Federal Rules holds that privileges are substantive under Erie and so governed by state law. ${ }^{61}$

As the cases convincingly demonstrate, the present approach to privilege source of law problems is inadequate. Privileges can be determinative of outcome and Erie will then compel application of state law. More often, however, a privilege's final effect on litigation is so uncertain that the outcome test would declare it procedural. Outcome, however, is but one level of Erie, and perliaps not its most important level. Beyond outcome, Erie requires analysis of relative state and federal interests in the particular issue in question.

Federal interests in a privilege issue are twofold. First, there is an interest stemming from the article III, section 2 grant of jurisdiction in diversity cases which makes a federal court more than just another state court. ${ }^{62}$ The problem, of course, is how much more. In Iovino v. Water-

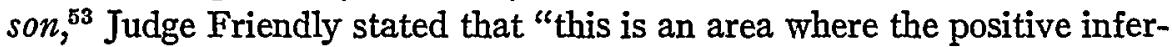
ence from article III and the 'necessary and proper' clause outweighs the negative inference from the limited grant of legislative power in article I, section 8 and the tenth amendment that must have formed the constitutional precept of Erie." ${ }^{24}$ A similar statement is found in Monarch Insurance Co. v. Spach, ${ }^{55}$ where the court noted that the article III duty to adjudicate carries with it the duty and the power to prescribe "such rules as will enable the federal district courts to fulfill these constitutional demands . . ." W6 While the extent of this power is uncertain, it seems

48 Palmer v. Fisher, 228 F.2d 603 (7th Cir. 1955), cert. denied sub nom. Fisher v. Pierce, 351 U.S. 965 (1956).

49 Willard Beach Air Brush Co. v. General Motors Corp., 118 F. Supp. 242 (D.N.J. 1953).

50 Humphries v. Pennsylvania R.R., 14 F.R.D. 177 (N.D. Ohio 1953); Brookshire v. Pennsylvania R.R., 14 F.R.D. 154 (N.D. Ohio 1953); Panella v. Baltimore \& Ohio R.R., 14 F.R.D. 196 (N.D. Ohio 1951).

E1 Krizak v. W. C. Brooks \& Sons, Inc., 320 F.2d 37 (4th Cir. 1963); Mass. Mut. Life Ins. Corp. v. Brei, 311 F.2d 463 (2d Cir. 1962) ; Padovani v. Liggett \& Myers Tobacco Co., 23 F.R.D. 255 (E.D.N.Y. 1959); Miller v. Pacific Mut. Life Ins. Co., 116 F. Supp. 365 (W.D. Mich. 1953).

62 Byrd v. Blue Ridge Rural Elec. Co-op, Inc., 356 U.S. 525 (1958).

53274 F.2d 41 (2d Cir. 1959), cert. denied sub nom. Carlin v. Iovino, 362 U.S. 949 (1960) (construing Rule 25(a) (1), permitting substitution of personal representatives of non-resident decedents).

54 Id. at 48.

65 281 F.2d 401 (5th Cir. 1960).

56 Id. at 407 . 
to relate to the court's power to control the conduct of litigation, as opposed to the rights being litigated. ${ }^{57}$ Since privileges go to more than the conduct of litigation, ${ }^{58}$ they would seem to fall outside the power conferred by article III.

A second federal interest stems from the longstanding federal policy that full disclosure in hitigation (both at the trial and, through discovery, at the pre-trial stage) is highly desirable and best serves the ends of justice. ${ }^{59}$ But unless a state has no substantial interests in the issue in question, which is not the case with privileges, it ill becomes a federal court to say that the state's legislature and judiciary are less interested than itself in promoting the ends of justice.

State interests in a diversity privilege issue seem overwhelming. The state permits and regulates the activities of doctors, lawyers and accountants at the primary level of activity. It is predominately a state matter whether justice for the state's people is best served by a particular privilege or by full disclosure in litigation; or whether business interests are furthered more by a broad construction of accountant and attorney privileges than by full disclosure; or whether full disclosure to a physician promotes community interests more than full disclosure to a court. ${ }^{.0}$

Finally, privileges involve determinations which may border or he outside the sphere of judicial competence. ${ }^{01}$ Where a state legislature has enacted a privilege, and the main thrust of hitigation concerns state created rights and obligations, federal courts should defer to the state. As the court in Massachusetts Mutual Life Insurance Co. v. Brei $i^{02}$ pointed out:

The privilege reflects a legislatively determined policy ... in that it affects private conduct before litigation arises. ... The physicianpatient privilege is more than a rule of procedure since it goes to relationships established and maintained outside the area of litigation, and affecting people's conduct at the stage of prinary private activity. ${ }^{63}$

Thus under the interest analysis approach, privileges in diversity litigation should be characterized as substantive.

57 Cf. Van Dusen v. Barrack, 376 U.S. 612 (1964); National Equip. Rental, Ltd. v. Szukhent, 375 U.S. 311 (1964). See Note, 52 CAIIF. L. REv.-(August, 1964).

58 See Louisell, supra note 29 , at 110-11.

50 Hickman v. Taylor, 329 U.S. 495 (1947).

60 These conclusions follow because the interests and rights which are undercut by the privileges are state created. Where they are federally created, different considerations are involved. See notes 73-84 infra and accompanying text.

61 See Louisell, supra note 29, at 117; Louisell \& Crippin, Evidentiary Privileges, 40 MTNN. L. Rev. 413 (1956).

62311 F.2d 463 (2d Cir. 1962).

63 Id. at 466 . 


\section{B. Federal Question Litigation ${ }^{64}$}

In a few federal question areas Congress has expressly provided for or against the use of state privilege law. ${ }^{65}$ In others it has done so by implication. ${ }^{66}$ In addition, the Rules of Decision Act commands federal adherence to state law except where the "Constitution or treaties of the United States or Acts of Congress otherwise require or provide." If "require" means that a federal court is bound by state law unless a federal policy would be substantially defeated, state privilege law almost always will govern. In this day of complicated interaction of laws, however, when congressional programs of great significance are enacted in broad terms, federal courts must have extensive powers both to formulate and apply federal law. As Mr. Justice Jackson persuasively stated:

A federal court sitting in a non-diversity case ... does not sit as a local tribunal. In some cases it may see fit ... to give the law of a particular state ... controlling effect, but in the last analysis the decision turns on the law of the United States .... Federal law ... is found in the federal Constitution, statutes or common law. Federal common law implements the federal Constitution and statutes, and is conditioned

${ }^{84}$ Two important preliminary considerations should be mentioned. Many of the federal question privilege cases originate in the administrative proceedings. This raises the question of whether any privilege law is apphicable in such proceedings. Although there is little case law, the leading writers in the field favor privileges in administrative proceedings. See 2

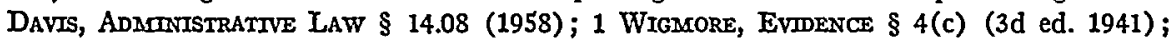
Miller, Challenges to the Attorney-Client Privilege, 49 VA. L. Rev. 262 (1963). The apphicability of some privilege law in administrative proceedings is recognized by dicta in Falsone v. United States, 205 F.2d 734, 739 (5th Cir.), cert. denied, 346 U.S. 864 (1953), and McMann v. SEC, 87 F.2d 377, 378 (2d Cir. 1937). The use of the attorney-client privilege in administrative proceedings is squarely upheld in CAB v. Air Transp. Ass'n, 201 F. Supp. 318 (D.D.C. 1961).

A second question is whether the Federal Rules, especially Rules 26(b) and 43(a), are applicable to judicial review of administrative proceedings. Of course, this does not include those proceedings that Rule 81 specifically exempts from the apphication of the Federal Rules. Litigants who contend that the Rules are apphicable generally assert that they require an application of state law. There has been considerable hitigation on this point, but the cases take widely divergent views. Compare Baird v. Koerner, 279 F.2d 633 (9th Cir. 1960), with Falsone v. United States, supra. See generally Fahey, Testimonial Privileges of Accountants in Federal Tax Fraud Investigations, 17 TAX L. REv. 491 (1962). For purposes of this Comment it is assumed that both questions can be answered in the affirmative.

65 Bankruptcy Act $\$ 8,66$ Stat. 423 (1952), 11 U.S.C. $\$ 44$ (a) (1958) provides that a spouse may be compelled to testify about business matters of the bankrupt, "any law . . of any State to the contrary notwithstanding." FED. R. CREM. P. 26 provides "The admissibility of evidence and the competency and privileges of witnesses shall be governed . . . by the principles of the common law as they nuay be interpreted ... in light of reason and experience."

86 Under the United States Torts Claim Act, 28 U.S.C. $\$ 1346$ (1958), state law is apphied to all issues arising out of a tort action against the Umited States, ineluding privileges. Awtry v. United States, 27 F.R.D. 399 (S.D.N.Y. 1961); Van Wie v. Umited States, 77 F. Supp. 22 (N.D. Iowa 1948). 
by them. Withm these limits, federal courts are free to apply the traditional common-law technique of decision . . . . ${ }^{67}$

Under this formulation federal courts can protect federal legislation from potential as well as actual conflicts, and more important, they can apply the rule best promoting federal legislative policy. ${ }^{08}$ That the courts have the power to make federal privilege law, however, does not answer the question of when they should do so.

Initially the Federal Rules, especially Rule 43(a), present a quasilegislative source for federal question privilege law. Under the Monarch, or equity-technique analysis, Rule 43(a) leaves open the privilege source of law question. ${ }^{60}$ The Federal Rules then, like the Rules of Decision Act, fail to resolve the privilege source of law problem. Consequently, considerations traditionally used in accommodating competing state and federal interests must be analyzed.

One such consideration is the largely interstitial nature of federal law. That is, federal courts tend to rely heavily on state law, making changes only as federal interests require. Thus, in many areas, whether for reasons of complexity, as in property law, ${ }^{70}$ or unfamiliarity or tradition, as in family law, ${ }^{71}$ federal courts defer to state law. Privileges, however, are neither overly complex nor infrequently handled. ${ }^{72}$

The following additional considerations have been advanced as relevant in federal question source of law determinations: (1) whether the policy underlying a federal statutory scheme requires uniformity of law on the issue in question; ${ }^{73}$ (2) whether state interests in the issue outweigh those of the federal government; ${ }^{74}(3)$ whether conduct at the prinary level of activity was done in reliance on state or federal law; ${ }^{75}$ (4) whether, from a practical viewpoint, it is more convenient for a

67 D'Oench, Duhme \& Co. v. Federal Deposit Ins. Corp., 315 U.S. 447, 471-72 (1942).

68 Cf. Textile Workers Union v. Lincoln Mills, 353 U.S. 448 (1956). See also Mishkin, The Federal "Question" in the District Courts, 53 Colons. L. REv. 157 (1953).

${ }^{69}$ See notes 34-38 supra and accompanying text.

70 See Reconstruction Fim. Corp. v. Beaver County, 328 U.S. 204 (1946).

71 See DeSylva v. Ballentine, 351 U.S. 570 (1956).

72 The following cases clearly demonstrate the ability of the federal courts to systematically develop a law of privilege. International Minerals \& Chem. Corp. v. Golding-Keene Co., 162 F. Supp. 137 (W.D.N.Y. 1958) ; Ellis-Foster Co. v. Umion Carbide \& Carbon Corp., 159 F. Supp. 917 (D.N.J. 1958); Georgia-Pacific Plywood Co. v. United States Plywood Corp., 18 F.R.D. 464 (S.D.N.Y. 1956) ; Radio Corp. Am. v. Rauland Corp., 18 F.R.D. 440 (N.D. Ill. 1955); Zemith Radio Corp. v. Radio Corp. Am., 121 F. Supp. 792 (D. Del. 1954); United States v. Umited Shoe Mach. Corp., 89 F. Supp. 357 (D. Mass. 1950).

${ }^{73}$ See United States v. Standard Oil Co., 332 U.S. 301 (1947); Clearfield Trust Co. v. United States, 318 U.S. 363 (1943).

74 See Kossick v. United Fruit Co., 365 U.S. 731 (1961).

75 See Hart, supra note 40, at 489-90, 508. 
federal court to apply state or federal law. The evaluation of those considerations constitutes what has been referred to as an interest analysis approach to source of law problems.

While uniformity has often been treated as a separate consideration, it is in realty only one facet of the interest analysis approach with the government as a litigant. Where uniformity has been held controlling, federal interests have been so strong that no deference to state interests was necessary. ${ }^{76}$ At times, however, this emphasis on uniformity lias subtly shifted to a presumption that the government as a litigant should not be subject to the vagaries of state law.$^{77}$ While treatment of the United States as a favorite son has evoked some criticism, it is unlikely to change.

In diversity litigation the interest analysis approach usually results in a triumph for state interests because state created rights and obhigations are all-pervasive. ${ }^{78}$ As a matter of symmetry, where federally created rights and obligations are involved, i.e. federal question litigation, the converse should follow. Unfortunately, problems arise because federal question litigation is built to a considerable extent upon a foundation of state law; ${ }^{79}$ state created rights and obhigations overlap federally created rights and obligations. Where there is a direct conflict the supremacy clause makes federal law paramount. ${ }^{80}$ As issues become more peripheral to the basic rights and obligations being hitigated, however, and the question becomes not one of conflict but of whether federal interests are sufficient to justify excluding state law, the problem is more complex. Here the extent of federal interests in the issue in question may vary with the nature of the federal function involved. Where the federal function is of a sort necessarily associated with the on-going activities of a central government, deference to state law, even for peripleral issues, seems unwise. ${ }^{81}$ Where, however, the federal function is less closely related to the idea of a central government, deference to state law, assuming sufficient state interests, seems reasonable. ${ }^{82}$

When neither a need for uniformity nor a preponderance of interests are present, certain lesser considerations may be relevant. For instance, the theory of reliance or "reasonable expectations" may assume importance. ${ }^{83}$ Source of law problems arise because of the dual nature of our

76 See cases cited note 73 supra. But see Note, 69 YALE L.J. 1428 (1960).

77 See Note, 69 YaIE L.J. 1428, 1442-46 (1960).

78 See Erie R.R. v. Tompkins, 304 U.S. 64 (1938). See also Degnan, supra note 39, at 288-90; Hill, supra note 43, at 574-89; Mishkin, supra note 43, at 798.

79 See Hart, supra note 40 , at 497.

$80 \mathrm{McCulloch}$ v. Maryland, 17 U.S. (4 Wheat.) 316 (1819).

81 See Clearfield Trust Co. v. United States, 318 U.S. 363 (1943). Cf. Textile Workers

Union v. Lincoln Mills, 353 U.S. 448 (1956).

82 See DeSylva v. Ballentine, 351 U.S. 570 (1956).

83 See, e.g., EERENzweIg, Conflict of Laws 355 (1962). 
federal system. In a wide range of activities the two parts of that system exercise concurrent power. Because there is often no way to tell at the primary level of activity whose law will govern litigation, the possibility of a state legislating in a manner which will eventually prove inconsistent with some federal policy, and consequently the possibility of an individual relying on the wrong law, is significant. Therefore, absent other considerations, a person's reasonable reliance on state law should not be frustrated. Finally, under some circumstances, judicial convenience may dictate that state law be ignored. ${ }^{84}$

Having set forth the basic considerations, the next step is to examine then in some particular federal question areas. Bankruptcy actions relate to matters closely identified with local interests. ${ }^{85}$ Bankruptcy law has shiglit importance to the functioning of a central government, and could liave been equally well handled by the states. ${ }^{86}$ People participating in bankruptcy generally have relied on state law, including state privilege law, in formulating their conduct. Consequently, in general, greater deference has been paid state law in bankruptcy proceedings than in other federal question litigation. ${ }^{87}$ What cases there are indicate similar deference to state privilege law. ${ }^{88}$

A very different picture is presented when a litigant claims a state privilege in an Internal Revenue proceeding. Here the second and ninth circuits have reached contrary conclusions. In Falsone v. United States, ${ }^{80}$ an accountant sought to avoid divulging tax records by claiming a privilege under a Florida statute. He contended that his appeal was a "civil action," and therefore that Rule 43(a) applied and required the application of state law. ${ }^{90}$ The court ran roughshod over the accountant's claims, lolding: (1) that the appeal was not a "civil action" but a continuation of the underlying administrative proceeding and that consequently Rule 43(a) and state law were irrelevant; (2) that administrative proceedings slould not be subject to normal rules of evidence; and (3) that while certain privileges might be acceptable in administrative proceedings the accountant-client privilege was not one of them.

In the ninth circuit the question arose in Baird v. Koerner. ${ }^{01}$ The

84 See notes 103-05 infra and accompanying text.

85 See Hill, The Erie Doctrine in Bankruptcy, 66 HARv. L. Rev. 1013, 1029 (1953). Sec also 4 COLLIERs, BaNkruptcx If 70.06.

${ }^{86}$ See Hill, supra note 85, at 1020.

87 Hill, supra note 85 , at 1035 .

88 See, e.g., In re Associated Gas \& Elec. Co., 59 F. Supp. 743 (S.D.N.Y. 1944).

89205 F.2d 734 (5th Cir.), cert. denied, 346 U.S. 864 (1953).

90 See note 63 supra for a discussion of what the defendant hoped to achicve through this claim.

91 279 F.2d 623 (9th Cir. 1961). Baird's reasoning is rejected in Colton v. United States, 306 F.2d 633 (2d Cir.), cert. denied, 371 U.S. 91 (1962). It is distinguished in FTC vo.St. 
Internal Revenue Service demanded the name of the chent for whom attorney Baird had made anonymous payment, although until the payment the government was unaware of a deficiency. Baird based his refusal to divulge the client's name on the California attorney-client privilege. The court held that appeal from a conviction of civil contempt resulting from refusal to answer at the administrative level was a "civil action" within the meaning of the Federal Rules so that Rule 43 (a) applied, ${ }^{92}$ and that since the qualifications for legal practice are determined by state law, the incidents of that practice should be determined by the same law. ${ }^{93}$ The court concluded that as no federal law compelled an attorney to disclose his client's name in this situation, application of state law was "required."

It is submitted that in sustaining the privilege, and thereby extricating attorney Baird from a very difficult position, the Baird court reached the right result but for the wrong reason. Application of state law was not "required." One major premise underlying the court's decision was that the state should determine the privileges incidental to the attorneyclient relationslip which it had created. This is questionable in light of the Supreme Court's recent decision in Sperry v. Florida. ${ }^{55}$ That case involved Florida's power to control the legal practice of a person enrolled before the Patent Office. The Court lield that since Congress rather than the state granted the right to practice, federal rather than state law must control its incidents. ${ }^{96}$ Of course, Sperry does not deal with practice before a court. Nevertheless, it is a strong indication that federal authorities have control over those who practice before them, at least when federal rights are in question. ${ }^{97}$

Regis Paper Co., 304 F.2d 731 (7th Cir. 1962). See also United States v. Summe, 208 F. Supp. 925 (E.D. Ky. 1962).

82279 F.2d at 628 .

${ }^{03} \mathrm{Id}$. at 632 .

04 Realistically, the decision in Baird is most likely not followed even in the ninth circuit because state courts and legislatures, in formulating their privilege law, have not considered the problems peculiar to the federal system, such as in the antitrust and patent areas. See, e.g., Garrison v. General Motors Corp., 213 F. Supp. 515 (S.D. Cal. 1963).

${ }_{95} 373$ U.S. 379 (1963). Sperry suggests that, in the absence of a congressional authorization, practice before administrative agencies, at least as to the conduct of attorneys, would be controlled by state law. It will probably never be necessary, however, to hold so simce nost agencies have such an authorization. E.g., Irr. REv. CODE OF $1954 \$ \S 7452$, 7805. See also note 102 infra. This, of course, does not answer the very difficult question relating to the source of the rules governing judicial review of an admimistrative proceeding, a question on which Baird and Falsone disagreed. The combination of the congressional authorization at the administrative level and the interest analysis approach at the judicial level would seem to make the source of those rules a natter of federal law.

96 Id. at $400-04$.

97 See note 95 supra. 
More fundamentally, the Baird court apparently failed to conisider the impact of state privilege law on the statutory investigatory power of the Internal Revenue Service. That statute's sweeping terms ${ }^{98}$ indicate congressional awareness that the power to investigate tax returns and compel full disclosure is essential to effective tax administration. Thus, federal interests seem overwhelming: there is federal power to regulate the incidents of tax practice, and federal policy strongly favors full disclosure in tax administration proceedings. In light of these federal interests, state law seems relevant only if it is the law best suited to promoting federal policies.9 ${ }^{99}$ As Mr. Justice Douglas put it in a slightly different context:

[S] tate law, if compatible with the purpose of $\S 301$, may be resorted to in order to find the rule that will best effectuate the federal policy.... Any state law applied, however, will be absorbed as federal law and will not be an independent source of private rights. ${ }^{100}$

Bankruptcy and tax collection represent polar areas of the privilege source of law problem. The reasons for applying state law in the one and for not applying it in the other are reasonably clear. In a civil antitrust case, however, the proper result is less obvious. Containment of monopolistic activities, while an important federal function, is not on a par with tax collection. Moreover, state interests are significant. The state lias substantial interests in business activities within its boundaries; those interests may be frustrated by an application of federal privilege law less protective than the state's. Moreover, the state has a significant interest in insuring that lawyers and accountants are protected from disclosures that would minimize their benefit to society by undermining the public's confidence.

Nevertheless, there are at least four countervailing federal interests. First, as in the tax cases the government's ability to prevent illegal restraint of trade depends upon the ability to gather information. ${ }^{101}$

98 "For the purposes of ascertaining the correctness of any return ... the Secretary ... is authorized (1) to examine any books, papers, records, or other data which may be relevant or material to such inquiry...." INT. REv. CODE OF 1954 § 7602. The Internal Revenue Service, through its regulations, exempts "privileged" information from this statute. 31 C.F.R. $\$ 10.22$ (a) (1959). Falsone indicated that this service regulation, if apphicable to accountants, would violate the statute. 205 F.2d at 74. Baird may be distinguishable on that point, however, since it involved an attorney's privilege claim.

99 It should also be noted that reliance could not have played a role in Baird's actions. He knew he was dealing with a matter governed by federal law and he knew or should have known that law, at least at the time of his actions, rejected state privilege law in Internal Revenue proceedings.

100 Textile Workers Union v. Lincoln Mills, 353 U.S. 448, 457 (1956).

101 In 1962 Congress at least partially solved the problem by enacting a statute which requires the FTC to recognize those privileges that would be recognized before a grand jury. Pub. Law No. 664, 87th Cong., 2d Sess. (Sept. 14, 1962). There is little case law on which 
Second, once an activity assumes a multistate character no concept of federalism calls for deference to state law. One purpose of the commerce clause was to grant power to regulate multistate activities which no single state could adequately control. ${ }^{102}$ When a business begins to affect interstate commerce the interests of a single state are seldom greater than those of the federal government. Third, because of the near impossibility in some antitrust cases of choosing which state's law to apply, judicial convenience requires wide judicial discretion in selecting the proper privilege law. ${ }^{103}$ Fourth, and finally, to the extent a court should take account of reasonable expectations there is evidence that many businessmen and corporations rely on federal privilege law in planning their activities. $^{104}$

While federal interests seem to preponderate in the antitrust area, they do not seem so overwhelming as to require that state law be ignored. Nevertheless, as a matter of desirability federal courts may want to compel persons engaged in interstate business to conform to federal privilege law. Factually, patent infringement actions present many of the problems discussed in antitrust proceedings. ${ }^{105}$ Consequently, much of that discussion is relevant here. In addition, patent infringement actions demonstrate that the use of state law to solve federal problems can have unfortunate consequences. Many corporate patent departments are composed predominately of attorneys. ${ }^{106}$ Broad state attorney-client privileges could be construed to cover all patent transactions by sucls attorneys, thereby making it almost impossible to prove patent infringement. While the value of the privilege may justify such a result, that

privileges are recognized in grand jury proceedings beyond that of attorney and client. See United States v. Lee, 107 Fed. 702 (E.D.N.Y. 1901).

102 Gibbons v. Ogden, 22 U.S. (9 Wheat.) 1 (1824). See Dowhing, Interstate Commerce and State Power-Revised Version, 27 VA. L. REv. 1, 2-6 (1940).

103 This problem is vividly presented in United States v. United Shoe Mach. Corp., 110 F. Supp. 295 (D. Mass. 1953). United Shoe did business in almost half the states. In an antitrust action the government sought to discover numerous communications; United Shoe raised a privilege clain. United States v. United Shoe Mach. Corp., 89 F. Supp. 357 (D. Mass. 1950). Sending states, receiving states, contracting states, and states of incorporation all had substantial interests in the various communications; any clioice between them would be haphazard at best. Consequently, the court wisely applied federal privilege law.

104 The following articles rely almost exclusively on federal law in advising the corporate bar: Austern, Corporate Counsel Communication; Is Anybody Listening?, 17 Bus. LAw. 868 (1962); Carson, Privileges and the Work Product Rule, 14 Bus. LAw. 771 (1959); Hanaway, Corporate Law Departments-A New Look, 17 Bus. LAw. 595 (1962) ; Hunt, Corporate Law Department Communications-Privilege and Discovery, 13 VAND. L. REv. 287 (1959); Maurer, Privileged Communications and the Corporate Counsel, 16 Bus. LAw. 959 (1961); Strack, Attorney-Client Privilege-House Counsel, 12 Bus. Law. 229 (1957).

105 See, e.g., Zenith Radio Corp. v. Radio Corp. Am., 121 F. Supp. 792 (D. Del. 1954).

106 E.g., United States v. United Shoe Macl. Corp., 89 F. Supp. 357, 360 (D. Mass. 1950), where 13 out of 21 nembers of the patent department were attorneys. 
judgment should be made under federal law. ${ }^{107}$ The practice and immunities of patent attorneys are properly federal questions. ${ }^{108}$

Finally, in patent cases there exists none of the uncertainty which creates reliance problems. From the moment a patent is created all who deal with it must recognize it as a federally created right governed by federal law. The very existence of the patent is notice to all concerned that federal law controls.

\section{CONCLUSION}

Privilege source of law problems have proved difficult for a variety of reasons. First, Erie R.R. v. Tompkins, because it represents a balance point between state and federal governments rather than a hard and fast rule of law, is incapable of definitive analysis. Attempts to fit Erie's basically flexible structure into ready-made pigeon holes, such as the outcome test, seem doomed to failure. ${ }^{109}$ Second, the Federal Rules have, at least in the privilege area, created more problems than they have solved. To the extent the Rules can control privileges, which will be primarily in the federal question area, they should do so expressly, rather than through ambiguous Rules, e.g., 26(b) and 43(a). Finally, because privileges arise as peripheral issues, it is difficult to classify them as either federal or state rights. In resolving these problems the most workable solution is the interest analysis approach. Until the courts realize that there are no simple, fixed answers in this area, privileges are likely to remain a focal point of dissension in the federal system.

Walter V. Stafford

107 Cf. Sola Elec. Co. v. Jefferson Elec. Co., 317 U.S. 173 (1942).

108 See Sperry v. Florida, 373 U.S. 379 (1963).

109 See notes 39-44 supra and accompanying text. 